\title{
Energy Input-Output Analysis for Production of Wheat under Different Planting Techniques and Herbicide Treatments
}

\author{
Sudesh Devi*, Virender Singh Hooda and Jagdev Singh \\ Department of Agronomy, COA, CCS HAU, Hisar, Haryana, 125004, India \\ *Corresponding author
}

\section{A B S T R A C T}

\begin{tabular}{|l|}
\hline Ke y w o r d s \\
Planting techniques, \\
Drill sowing, Bed \\
planting, \\
Herbicides, Energy \\
productivity, \\
Nonrenewable \\
energy, Renewable \\
energy, Specific \\
energy
\end{tabular}

\section{Introduction}

Wheat (Triticum aestivum L.) is a main cereal crop cultivated throughout the world along with rice, maize, barley, rye, sorghum, oats and millet. It is grown under irrigated as well as rainfed conditions worldwide. Based on Ministry of Agriculture and Farmers Welfare of India statistics, India produced about 98.38 million tonnes of wheat in 2016-17. Energy is one of the most valuable inputs in agriculture for crop production. Agriculture itself is an energy consumer and energy supplier in the form of bio-energy (Alam et al., 2005). In response to fast growing populations, limited supply of arable land and desire for an increasing standard of living, the concern about energy use in agriculture has been gaining importance.

Agriculture is both a producer and consumer of energy. It uses large quantities of locally available non-commercial energies, such as seed, manure and animate energy and commercial energies directly and indirectly in the form of diesel, electricity, fertilizer, plant 
protection, chemicals, irrigation water and machinery. Efficient use of energies helps to achieve increased production and productivity and contributes to the economy, profitability and competitiveness of agriculture sustainability. Although energy consumption in agriculture is much lower than the other sectors, energy usage as input and output in the agriculture sector is a very important issue due to its large agricultural potential and the size of rural area in India.

Energy consumption per unit area in agriculture is directly related to the development of farming technology and the production levels. Energy use is one of the key indicators for developing more sustainable agricultural practice. The amount of energy used in agricultural production, processing and distribution is significantly higher. A sufficient supply of the right amount of energy and its effective and efficient use are necessary for an improved agricultural production. The prevalence of high consumption of non-renewable energies is a challenge in relation to agriculture. The available evidence suggests that the excessive consumption of certain agricultural inputs, not only has inhibited the increase in production, but also reduced it in some cases (Omani and Chizari, 2008). The energy agriculture relationship is becoming more and more important with the intensification of the cropping systems, which is considered to be the only means of raising agricultural output in land scarce situations. Timely solving the problems and large scale implementing the approaches of developing the agricultural energy system will contribute to independence of energy supply for overcoming the energy crisis and reviving national farming, which will be a considerable input in ensuring the national food security.

Therefore the present study was undertaken with the objective to analyze the input, output and net return energy of different planting techniques i.e. drill sowing and bed planting with weed management treatments using different herbicide combinations and to identify energy efficient planting technique and herbicide treatment with for satisfactory energy output.

\section{Materials and Methods}

A field experiment was carried out at Agronomy farm area, CCS Haryana Agricultural University, Hisar, Haryana, India during Rabi season of 2012-13. The mean weekly maximum and minimum temperature ranged between 11.6 to $35.7^{\circ} \mathrm{C}$ and 1.6 to $20.5^{\circ} \mathrm{C}$, respectively and about $114.6 \mathrm{~mm}$ rainfall was received during crop growing season; while sunshine ranged between 2.0 to $9.5 \mathrm{hrs}$ during crop season. The soil of the field was sandy loam in texture, slightly alkaline in $\mathrm{pH}$ (8.3), low in organic carbon $(0.33 \%)$, poor in available nitrogen (182 $\mathrm{kg} / \mathrm{ha}$ ) and medium in available phosphorus (13 $\mathrm{kg} / \mathrm{ha})$ and rich in available potassium (365 kg/ha). The experiment was laid out in a split plot design with five planting techniques [drill sowing at $20 \mathrm{~cm}$ (A1), $18 \mathrm{~cm}$ (A2) and $16 \mathrm{~cm}$ (A3), bed planting with three (A4) and two rows (A5)] in main plot and five weed management treatments [pinoxaden $50 \mathrm{~g} / \mathrm{ha}$ (Z1), RM of carfentrazone and metsulfuron 25 $\mathrm{g} / \mathrm{ha}$ (Z2), pinoxaden $50 \mathrm{~g} / \mathrm{ha}+\mathrm{RM}$ of carfentrazone and metsulfuron $25 \mathrm{~g} / \mathrm{ha}$ (Z3), weed free (Z4) and weedy check (Z5)] in subplots, replicated thrice. The crop was raised with standard package of practices given by CCSHAU, Hisar and details of different cultural operations carried out during pre and post sowing of wheat in the experiment field are presented in Table 1. Energy inputs and outputs of wheat crop were estimated using crop management (machinery operations and amount of input used) and biomass production records. The amount of energy consumption per unit area of different 
inputs (human labour, machinery, implements, chemical fertilizers, diesel fuel, water, herbicides and wheat seed) and outputs (grain and straw) was estimated by using energy equivalents (Table 2) (Devasenapathy et al., 2009; Tuti et al., 2012; Dhaka et al., 2015; Sorokhaibam et al., 2016; Negi et al., 2016) and formulae used by Chaudhary et al., (2006), Khan and Hussain (2007),
Devasenapathy et al., (2009) and given in Table 3. According to energy input and output, cost of cultivation, yield, energy use efficiency, energy productivity, net energy, specific energy, energy profitability, energy intensiveness, energy intensity in physical and economic terms were calculated (Kumar et al., 2017) as following:

$$
\begin{aligned}
& \text { Energy Use Efficiency (EUE) = Energy Output (MJ/ha)/Energy Input (MJ/ha) } \\
& \text { Energy Productivity }(\mathrm{kg} / \mathrm{MJ})=\text { Wheat grain yield }(\mathrm{kg} / \mathrm{ha}) / \text { Energy Input }(\mathrm{MJ} / \mathrm{ha}) \\
& \text { Net Energy }(\mathrm{MJ})=\text { Energy Output }(\mathrm{MJ} / \mathrm{ha})-\text { Energy Input }(\mathrm{MJ} / \mathrm{ha}) \\
& \text { Specific Energy }(\mathrm{MJ} / \mathrm{kg})=\text { Energy Input }(\mathrm{MJ} / \mathrm{ha}) / \text { wheat grain yield }(\mathrm{kg} / \mathrm{ha}) \\
& \text { Energy Profitability }=\text { Net Energy }(\mathrm{MJ} / \mathrm{ha}) / \text { Energy Input }(\mathrm{MJ} / \mathrm{ha}) \\
& \text { Energy Intensiveness (MJ/Rs.) = Energy Input (MJ/ha)/ Cost of cultivation (Rs./ha) } \\
& \text { Energy intensity in physical terms }(\mathrm{MJ} / \mathrm{kg})=\text { Energy Input } / \text { wheat biological yield }(\mathrm{kg} / \mathrm{ha}) \\
& \text { Energy intensity in economic terms (MJ/Rs.) = Total Energy output /Cost of cultivation }
\end{aligned}
$$

Also the share of direct energy, indirect energy, renewable energy and non-renewable energy was calculated from different sources (Devasenapathy et al., 2009; Beheshti et al., 2010). The direct sources of energy are those that release the energy directly like human labour, animal, fuel (petrol, diesel), electricity etc. The direct energy may be further divided as renewable (natural but can be subsequently replenished in due course of time) and non renewable sources (not renewable at least in near further say next 100 years) of energy depending upon their replenishment (Table 5). Whereas, indirect sources of energy are those which don't release energy directly but release energy by conversion process (Table 6).

\section{Results and Discussion}

\section{Analysis of input energy use in wheat production}

Total energy used in various farm operations under flat bed sowing (conventional method) during wheat production was $15695.89 \mathrm{MJ} / \mathrm{ha}$ and under raised bed sowing was 15586.84 $\mathrm{MJ} / \mathrm{ha}$ (Table 4). The difference in total energy in these two methods was due to difference in post irrigation water quantity and energy consumed in sowing. There was $25 \%$ less water consumption in raised bed planting as compared to flat bed planting; hence a difference in energy of water was recorded. The chemical fertilizer consumed 50.59 and $50.94 \%$ of total energy inputs followed by irrigation 15.12 and $12.7 \%$ under flat and raised bed sowing respectively, during production period. Diesel energy was mainly consumed for land preparation, sowing and threshing. That's why it very important and remarkable to study the energy inputs and their share in production. Similar to the results of this study, the studies of Hosseinpanahi and Kafi (2012) and Giampietro et al., (1992) have also demonstrated that nitrogen fertilizer allocated the largest part of energy consumption among chemicals in crop production. When weed management is included (manual weeding), total energies used during wheat production were 16480.69 $\mathrm{MJ} / \mathrm{ha}$ and $16371.64 \mathrm{MJ} / \mathrm{ha}$ under flat and raised bed sowing, respectively. The manual weeding consumed $2 \%$ of total input energy under both sowing methods in wheat 
production (Figure 1). Under flat bed sowing (conventional planting), land preparation consumed maximum energy (36\% of total energy) of direct input energy (including renewable and non-renewable sources) followed by threshing $(27 \%)$ and manual weeding $(20 \%)$ as shown in Table 5. Maximum part of indirect energy came from chemical fertilizer (7938 MJ/ha) followed by sowing (1847.92 MJ/ha) (Table 6) and total energy of tractor i.e. $374.85 \mathrm{MJ} / \mathrm{ha}$ (Table 3). Maximum part of total input energy of wheat production came from indirect sources like chemical fertilizer, machinery etc. In India, Singh et al., (2007) reported that average grain yield, total energy input and output, in wheat production were $25.51 \mathrm{q} / \mathrm{ha}, 15572.2$ and 63846.02 MJ/ha, respectively.

The results of the main study demonstrated in this experiment are shown in Table 7. Total input energy used for wheat crop production for conventional (flat bed) planting techniques viz. drill sowing with 16,18 , and $20 \mathrm{~cm}$ was 15929.49 MJ/ha; whereas for raised bed planting total input energy was 15766.27 $\mathrm{MJ} / \mathrm{ha}$ (Table 7). The difference in total input energy between this two planting techniques (flat and raised bed sowing) was just one percent (163.22 MJ/ha). Drill sowing with 18 $\mathrm{cm}$ row spacing produced maximum total output energy per hectare i.e. 181226 MJ followed by drill sowing with $20 \mathrm{~cm}$ (177931.9 MJ) and bed planting with three row (176256.2 MJ) of wheat, whereas, two row bed planting produced lower total output energy i.e. 168739.1 MJ compared to other planting technique.

The increase in net energy was 5.9, 8.1, 0.8 and 4.9 per cent under drill sowing at 20, 18 and $16 \mathrm{~cm}$ and bed planting with three rows respectively, with respect to bed planting with two rows. Drill sowing with $18 \mathrm{~cm}$ recorded highest value of energy use efficiency (11.38), energy productivity $(0.335 \mathrm{~kg} / \mathrm{MJ})$, energy profitability (10.38), energy intensity in economic terms $(3.50 \mathrm{MJ} / \mathrm{Rs})$ followed by bed planting with three rows and drill sowing with $20 \mathrm{~cm}$. Bed planting with two rows of wheat showed higher value of specific energy (3.25 $\mathrm{MJ} / \mathrm{kg}$ ) followed by drill sowing with $16 \mathrm{~cm}$ $(3.23 \mathrm{MJ} / \mathrm{kg})$. The value of specific energy was lower under drill sowing with $18 \mathrm{~cm}$ which makes it better planting techniques in terms of energy. In spite of consumption of higher input energy, under flat bed planting higher value of energy intensiveness was recorded as compared to raised bed planting which might is due to lower cost of cultivation estimates under conventional planting. Drill sowing with $20 \mathrm{~cm}$ and three row bed planting showed higher value of energy intensity in physical terms which can be attributed to higher biological yield and input energy consumption. The higher energy-use efficiency of wheat genotypes was mainly attributed to higher yield production with use of lesser energy utilization (Maurya et al., 2014).

With respect to weed management treatments, energy use efficiency (11.47), energy profitability (10.47), energy productivity (0.339), and energy intensity in terms of economic (3.55 MJ/Rs) were higher with tank mix application of pinoxaden $(50 \mathrm{~g} / \mathrm{ha})$ with RM of carfentrazone+metsulfuron-methyl (25 g/ha) @ 35 days after sowing (Table 7 and Fig 2 ). This may attributed to higher production and lower input energy. Whereas, weed free treatment produced significantly higher grain and biological yield over other weed management treatments, but to achieve that $4.58,4.62,4.52$ and 4.80 percent extra energy was used over Z1, Z2, Z3 and Z5, respectively (Table 7). Weedy check showed higher value of specific energy (3.47 MJ/kg) and energy intensity in physical terms $(1.31 \mathrm{MJ} / \mathrm{kg})$, followed by alone application of pinoxaden (50 g/ha) with the values 3.11 and $1.20 \mathrm{MJ} / \mathrm{kg}$ (Fig. 2). 
Table.1 Schedule of cultural operations carried out in the experimental field

\begin{tabular}{|c|c|c|c|}
\hline $\begin{array}{l}\text { Sr. } \\
\text { No. }\end{array}$ & $\begin{array}{l}\text { Nature of } \\
\text { operations }\end{array}$ & $\begin{array}{l}\text { Date of } \\
\text { operations }\end{array}$ & Details of operations \\
\hline \multicolumn{4}{|c|}{ A. Pre-sowing operations: } \\
\hline 1. & $\begin{array}{l}\text { Pre-sowing } \\
\text { irrigation }\end{array}$ & 28.11.2012 & Irrigation was done with canal water \\
\hline 2. & $\begin{array}{l}\text { Seed bed } \\
\text { preparation }\end{array}$ & 06.12 .2012 & $\begin{array}{l}\text { At proper moisture condition the field was ploughed twice by disc harrow } \\
\text { and once by cultivator followed by planking with tractor }\end{array}$ \\
\hline 3. & Layout & 09.12 .2012 & Layout was performed \\
\hline 4. & $\begin{array}{l}\text { Sowing and } \\
\text { fertilizers } \\
\text { application }\end{array}$ & 10.12.2012 & $\begin{array}{l}\text { Sowing of variety WH711 was done by seed-cum fertilizer drill and bed } \\
\text { planter as per treatments at } 5-6 \mathrm{~cm} \text { depth using } 125 \mathrm{~kg} \text { seed/ha and } \\
\text { recommended dose of fertilizers was applied (half of the nitrogen }(60 \\
\mathrm{kg} / \mathrm{ha} \text { ) as per treatments and recommended dose of phosphorus i.e. } 60 \\
\mathrm{~kg} / \mathrm{ha} \text { ) }\end{array}$ \\
\hline \multicolumn{4}{|c|}{ B. Post Sowing operations: } \\
\hline 1. & Final layout & 11.12.2012 & Final layout, channels and bunds were prepared \\
\hline 2. & $\begin{array}{l}\text { Top dressing of } \\
\text { remaining half } \\
\text { of } \mathrm{N}\end{array}$ & 02.01 .2013 & $\begin{array}{l}\text { Remaining half dose of nitrogen }(60 \mathrm{~kg} / \mathrm{ha}) \text { was top dressed at } 1^{\text {st }} \\
\text { irrigation }\end{array}$ \\
\hline 3. & Weeding & - & $\begin{array}{l}\text { The weeds were removed by hand pulling from time to time in all the } \\
\text { weed free plots throughout the crop season }\end{array}$ \\
\hline 4. & Irrigation & $\begin{array}{l}02.01 .2013 \\
05.03 .2013 \\
11.04 .2013\end{array}$ & $\begin{array}{l}\text { Three irrigations with canal water were applied at } 23,85,122 \text { days after } \\
\text { sowing }\end{array}$ \\
\hline 5. & Harvesting & 25.04 .2013 & $\begin{array}{l}\text { Harvesting was done manually with the help of sickles by cutting the } \\
\text { plants just above the ground level from the net area of each plot } \\
\text { separately. Bundles were made and left in the field for drying in sun }\end{array}$ \\
\hline 6. & Threshing & 06.05 .2003 & $\begin{array}{l}\text { Before threshing the biological yield (grain }+ \text { straw) was recorded for } \\
\text { each net plot. Threshing was done with the help of miniplot thresher. The } \\
\text { grains collected from each net plot were weighted }\end{array}$ \\
\hline
\end{tabular}


Table.2 Energy coefficient (equivalent) of different inputs and outputs in wheat production

\begin{tabular}{|c|c|c|c|c|}
\hline \multicolumn{2}{|c|}{ Particulars } & \multirow{2}{*}{$\begin{array}{l}\text { Units } \\
\text { Hour (h) } \\
\text { h }\end{array}$} & \multirow{2}{*}{$\begin{array}{l}\text { Energy coefficient } \\
\text { (MJ/unit) } \\
\\
\\
1.96 \\
1.57\end{array}$} & \multirow{2}{*}{$\begin{array}{l}\text { Remarks } \\
1 \text { Adult women is equal } \\
\text { to } 0.8 \text { adult man }\end{array}$} \\
\hline Inputs & $\begin{array}{l}\text { 1. Human Labour } \\
\checkmark \quad \text { Adult man } \\
\checkmark \quad \text { Woman }\end{array}$ & & & \\
\hline & 2. Diesel Fuel & Litre & 56.31 & $\begin{array}{l}\text { It includes the cost of } \\
\text { lubricant }\end{array}$ \\
\hline & $\begin{array}{l}\text { 3. Machinery } \\
\begin{aligned} \checkmark & \text { Tractor } \\
\checkmark & \text { Farm-machinery } \\
\checkmark & \text { Thresher } \\
\checkmark & \text { Sickle }\end{aligned}\end{array}$ & $\begin{array}{c}\text { Kilogram (kg) } \\
\qquad \begin{array}{c}\mathrm{kg} \\
\mathrm{kg} \\
\mathrm{h}\end{array}\end{array}$ & $\begin{array}{l}180.00 \\
62.70 \\
17.40 \\
0.031\end{array}$ & $\begin{array}{l}\text { Distribute the weight of } \\
\text { machinery equally over } \\
\text { the total life span of the } \\
\text { machinery (in hours) }\end{array}$ \\
\hline & $\begin{array}{l}\text { 4. Manual implements } \\
\qquad \begin{array}{ll}\checkmark & \text { Sickle } \\
\checkmark & \text { Khurpa } \\
\checkmark & \text { Kasola } \\
\checkmark & \text { Spade }\end{array}\end{array}$ & $\begin{array}{l}\mathrm{h} \\
\mathrm{h} \\
\mathrm{h} \\
\mathrm{h}\end{array}$ & $\begin{array}{l}0.031 \\
0.031 \\
0.188 \\
0.314\end{array}$ & $\begin{array}{l}\text { These implements were } \\
\text { used in many } \\
\text { intercultural operations } \\
\text { like weeding. Sickle used } \\
\text { for manual harvesting of } \\
\text { crop }\end{array}$ \\
\hline & $\begin{array}{ll}\text { 5. Chemical Fertilizers } \\
\qquad \quad \text { Nitrogen } \\
\checkmark \quad \text { Phosphate }\left(\mathrm{P}_{2} \mathrm{O}_{5}\right) \\
\checkmark \quad \text { Potash }\left(\mathrm{K}_{2} \mathrm{O}\right)\end{array}$ & $\begin{array}{l}\mathrm{kg} \\
\mathrm{kg} \\
\mathrm{kg}\end{array}$ & $\begin{array}{c}60.60 \\
11.10 \\
6.70\end{array}$ & $\begin{array}{l}\text { Estimate the quantity of } \\
\text { nutrient in the chemical } \\
\text { fertilizer. Then compute } \\
\text { the amount of energy } \\
\text { input from chemical }\end{array}$ \\
\hline & $\begin{array}{l}\text { 6. Pesticides } \\
\begin{aligned} \checkmark & \text { Herbicides } \\
\checkmark & \text { Insecticides } \\
\checkmark & \text { Fungicides }\end{aligned}\end{array}$ & $\begin{array}{l}\mathrm{kg} \\
\mathrm{kg} \\
\mathrm{kg}\end{array}$ & $\begin{array}{l}288 \\
237 \\
196\end{array}$ & \\
\hline & 7. Water & $\mathrm{m}^{3}$ & 1.02 & \\
\hline & 8. Seed & $\mathrm{kg}$ & 14.70 & \\
\hline \multirow[t]{2}{*}{ Outputs } & 1. Grain wheat & $\mathrm{kg}$ & 14.70 & \\
\hline & 2. Straw & $\mathrm{kg}$ & 12.50 & \\
\hline
\end{tabular}


Table.3 Energy consumption and energy input-output relationship in wheat production under different planting techniques and weed management treatments

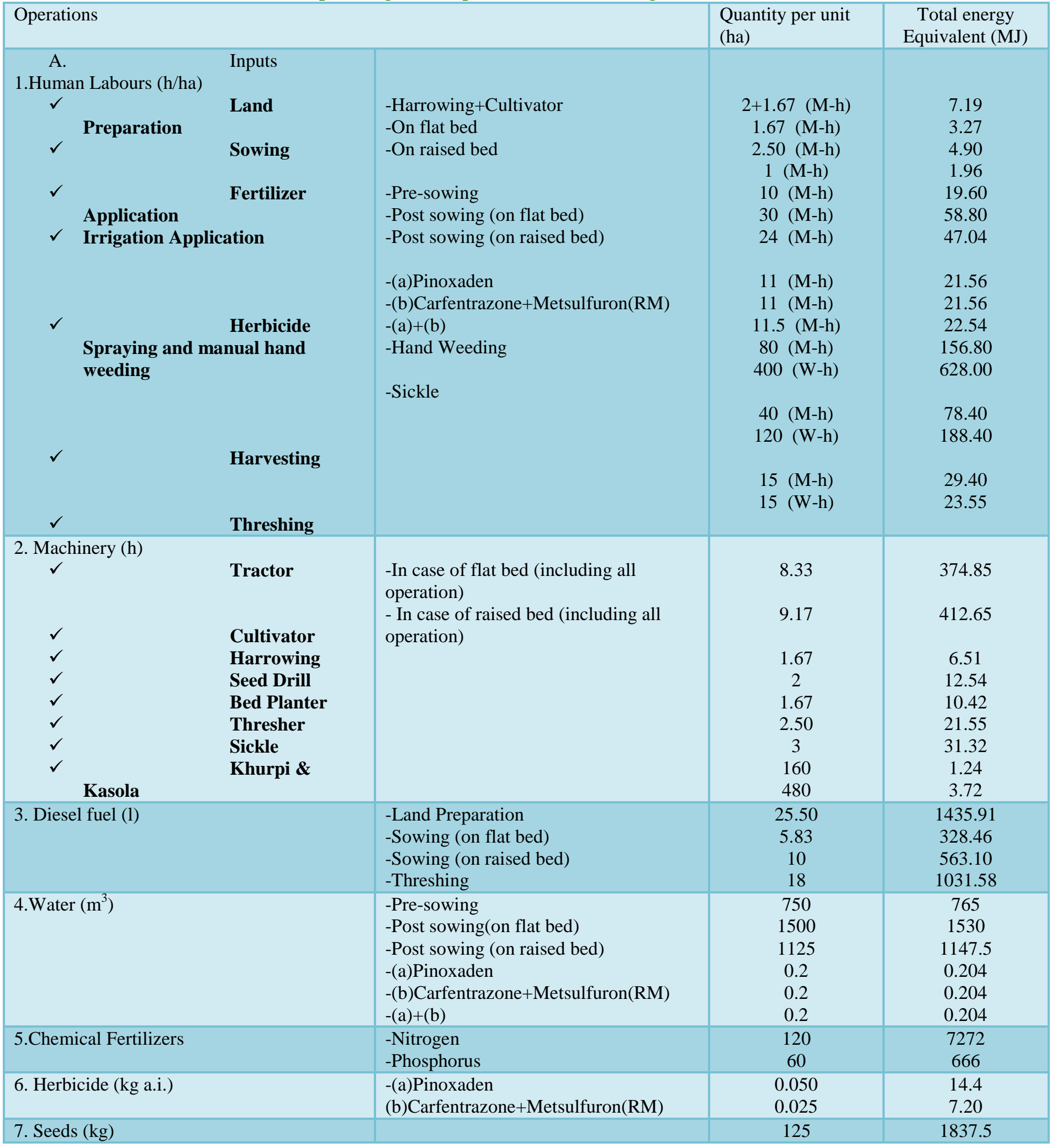


Table.4 Operation wise energy values of wheat crop excluding weed management

\begin{tabular}{|c|c|c|}
\hline Operations & Energy (MJ/ha) & Percentage of total energy input (\%) \\
\hline \multicolumn{3}{|c|}{ Flat Bed Sowing } \\
\hline 1. Land Preparation & 1462.15 & 9.32 \\
\hline 2. Seed & 1837.50 & 11.71 \\
\hline 3. Sowing & 0716.99 & 4.57 \\
\hline 4. Fertilizer & 7939.96 & 50.59 \\
\hline 5. Irrigation & 2373.40 & 15.12 \\
\hline 6. Harvesting & 0268.04 & 1.71 \\
\hline 7. Threshing & 1097.85 & 6.99 \\
\hline Total Energy & 15695.89 & 100 \\
\hline \multicolumn{3}{|c|}{ Raised Bed Sowing } \\
\hline 1. Land Preparation & 1462.15 & 9.38 \\
\hline 2. Seed & 1837.50 & 11.79 \\
\hline 3. Sowing & 1002.20 & 6.43 \\
\hline 4. Fertilizer & 7939.96 & 50.94 \\
\hline 5. Irrigation & 1979.14 & 12.7 \\
\hline 6. Harvesting & 0268.04 & 1.72 \\
\hline 7. Threshing & 1097.85 & 7.04 \\
\hline Total Energy & 15586.84 & 100 \\
\hline
\end{tabular}

Table.5 Sources of direct energy in weed free condition

\begin{tabular}{|c|c|c|c|c|c|c|c|c|}
\hline \multirow[t]{3}{*}{ Field Operation } & \multicolumn{7}{|c|}{ Direct Energy (MJ/ha) } & \multirow{3}{*}{$\begin{array}{c}\text { Grand } \\
\text { Total }\end{array}$} \\
\hline & \multicolumn{2}{|c|}{ Renewable } & \multirow[t]{2}{*}{ Total } & \multicolumn{3}{|c|}{ Non-renewable } & \multirow[t]{2}{*}{ Total } & \\
\hline & Man & Woman & & Petrol & Diesel & Electricity & & \\
\hline Land Preparation & 7.19 & - & 7.19 & - & 1435.91 & - & 1435.91 & 1443.10 \\
\hline Sowing & 3.27 & - & 3.27 & - & 328.46 & - & 328.46 & 331.73 \\
\hline Fertilizer Application & 1.96 & - & 1.96 & - & - & - & - & 1.96 \\
\hline Irrigation Application & 78.40 & - & 78.40 & - & - & - & - & 78.40 \\
\hline Manual weeding & 156.80 & 628.00 & 784.80 & - & - & - & - & 784.80 \\
\hline Harvesting & 78.40 & 188.40 & 266.8 & - & - & - & - & 266.8 \\
\hline Threshing & 29.40 & 23.55 & 52.95 & - & 1031.58 & - & 1031.58 & 1084.53 \\
\hline Total & 355.42 & 839.95 & 1195.37 & - & 2795.95 & - & 2795.95 & 3991.32 \\
\hline
\end{tabular}

Fig.1 Energy Fraction of different operations including hand weeding in flat bed and raised bed sowing
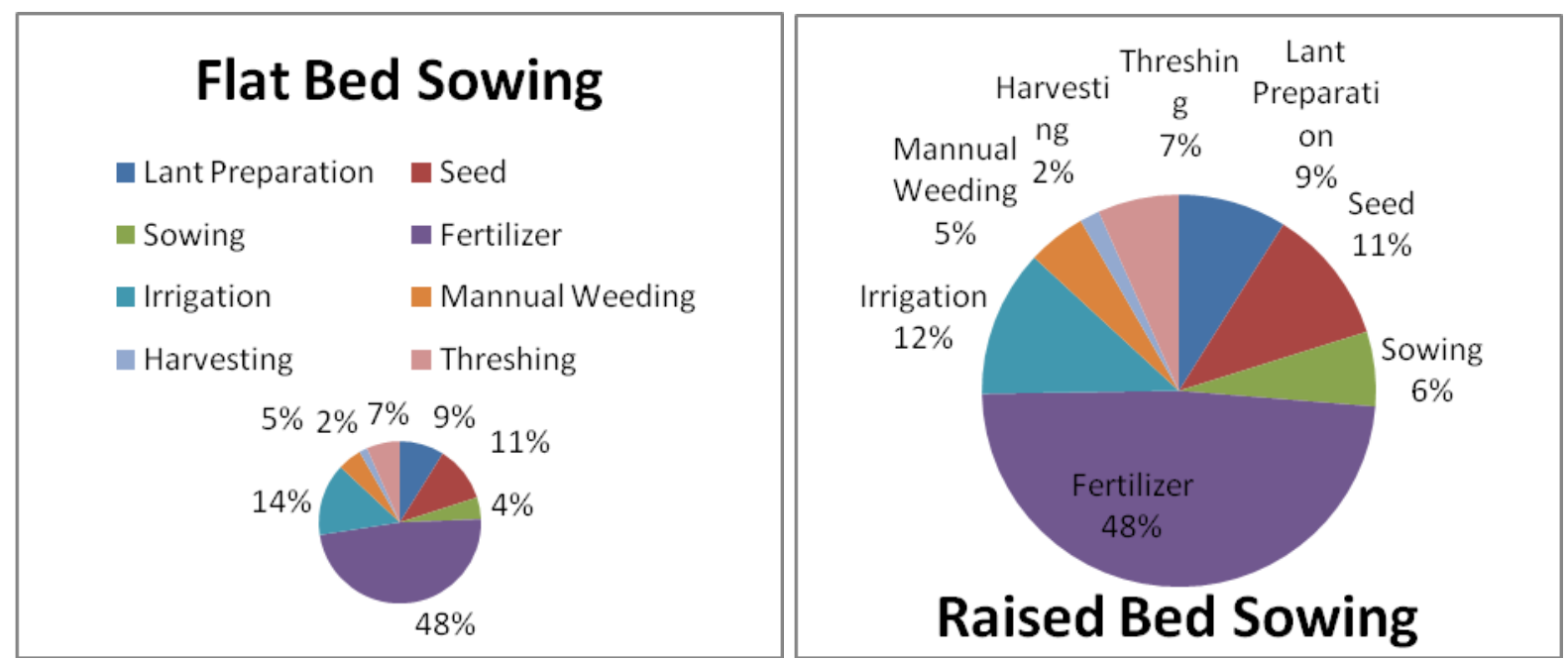
Table.6 Sources of indirect energy in weed free condition

\begin{tabular}{|c|c|c|c|c|c|c|c|c|}
\hline \multirow{3}{*}{$\begin{array}{l}\text { Field } \\
\text { Operation }\end{array}$} & \multicolumn{7}{|c|}{ Indirect Energy $(\mathrm{MJ} / \mathrm{ha})$} & \multirow{3}{*}{$\begin{array}{c}\text { Grand } \\
\text { Total }\end{array}$} \\
\hline & \multicolumn{2}{|c|}{ Renewable } & \multirow[t]{2}{*}{ Total } & \multicolumn{3}{|c|}{ Non-renewable } & \multirow[t]{2}{*}{ Total } & \\
\hline & Seed & FYM & & Chemical & Fertilizer & Machinery & & \\
\hline $\begin{array}{l}\text { Land } \\
\text { Preparation }\end{array}$ & - & - & - & - & - & 19.05 & 19.05 & 19.05 \\
\hline Sowing & 1837.50 & - & 1837.50 & - & - & 10.42 & 10.42 & 1847.92 \\
\hline Fertilizer & - & - & - & - & 7938 & - & 7938 & 7938 \\
\hline $\begin{array}{l}\text { Irrigation } \\
\text { Application }\end{array}$ & - & - & - & - & - & - & - & - \\
\hline $\begin{array}{l}\text { Manual } \\
\text { weeding }\end{array}$ & - & - & - & - & - & 3.72 & 3.72 & 3.72 \\
\hline Harvesting & - & - & - & - & - & 1.24 & 1.24 & 1.24 \\
\hline Threshing & - & - & - & - & - & 31.32 & 31.32 & 31.32 \\
\hline Total & 1837.50 & - & 1837.50 & - & 7938 & $\begin{array}{c}(65.75+ \\
374.85 *) \\
440.60\end{array}$ & 8378.60 & 10216.10 \\
\hline
\end{tabular}

*Tractor energy (see in Table 3)

Table.7 Effect of different planting techniques and weed management treatments on different energy indices

\begin{tabular}{|c|c|c|c|c|c|c|c|c|c|}
\hline $\begin{array}{l}\text { Treat- } \\
\text { ments }\end{array}$ & $\begin{array}{c}\text { Input } \\
\text { Energy } \\
(\mathrm{MJ} / \mathrm{ha})\end{array}$ & $\begin{array}{l}\text { Output } \\
\text { Energy } \\
\text { of } \\
\text { Grain } \\
\text { (MJ/ha) }\end{array}$ & $\begin{array}{l}\text { Output } \\
\text { Energy } \\
\text { of } \\
\text { Straw } \\
\text { (MJ/ha) }\end{array}$ & $\begin{array}{c}\text { Total } \\
\text { Output } \\
\text { Energy } \\
\text { (MJ/ha) }\end{array}$ & $\begin{array}{c}\mathrm{NE} \\
(\mathrm{MJ} / \mathrm{ha})\end{array}$ & EUE & $\begin{array}{c}\text { Cost of } \\
\text { Cultiva } \\
\text { tion }\end{array}$ & GY & BY \\
\hline \multicolumn{10}{|c|}{ Planting Techniques } \\
\hline A1 & 15929.49 & 76469.40 & 101462.50 & 177931.90 & 162002.41 & 11.17 & 51708 & 20.81 & 53.28 \\
\hline $\mathrm{A} 2$ & 15929.49 & 78351.00 & 102875.00 & 181226.00 & 165296.51 & 11.38 & 51708 & 21.32 & 54.24 \\
\hline A3 & 15929.49 & 72573.90 & 097587.50 & 170161.40 & 154231.91 & 10.68 & 51708 & 19.75 & 50.98 \\
\hline A4 & 15766.27 & 76381.20 & 099875.00 & 176256.20 & 160489.93 & 11.18 & 52091 & 20.78 & 52.74 \\
\hline A5 & 15766.27 & 71339.10 & 097400.00 & 168739.10 & 152972.83 & 10.70 & 52091 & 19.42 & 50.58 \\
\hline $\mathrm{SEm} \pm$ & - & - & - & - & - & - & - & 0.30 & 0.48 \\
\hline $\begin{array}{l}\mathrm{CD} \\
\text { at } 5 \%\end{array}$ & - & - & - & 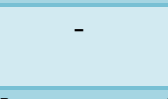 & 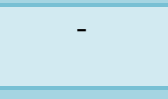 & - & - & 0.97 & 1.55 \\
\hline \multicolumn{10}{|c|}{ Weed Management Treatments } \\
\hline $\mathrm{Z} 1$ & 15688.43 & 74073.30 & 101012.50 & 175085.80 & 159397.37 & 11.16 & 50587 & 20.16 & 52.48 \\
\hline $\mathrm{Z} 2$ & 15681.23 & 76307.70 & 099662.50 & 175970.20 & 160288.97 & 11.22 & 49547 & 20.77 & 52.66 \\
\hline $\mathrm{Z3}$ & 15696.61 & 78145.20 & 101950.00 & 180095.20 & 164398.59 & 11.47 & 50801 & 21.26 & 53.89 \\
\hline $\mathrm{Z} 4$ & 16440.79 & 80350.20 & 103912.50 & 184262.70 & 167821.91 & 11.21 & 57973 & 21.86 & 55.12 \\
\hline Z5 & 15652.27 & 66238.20 & 092662.50 & 158900.70 & 143248.43 & 10.15 & 50396 & 18.02 & 47.68 \\
\hline SEm \pm & - & - & - & - & - & - & - & 0.27 & 0.44 \\
\hline $\begin{array}{l}\mathrm{CD} \\
\text { at } 5 \%\end{array}$ & - & - & - & - & - & - & - & 0.77 & 1.26 \\
\hline
\end{tabular}


Fig.2 Effect of planting techniques and weed management methods on different energy indices

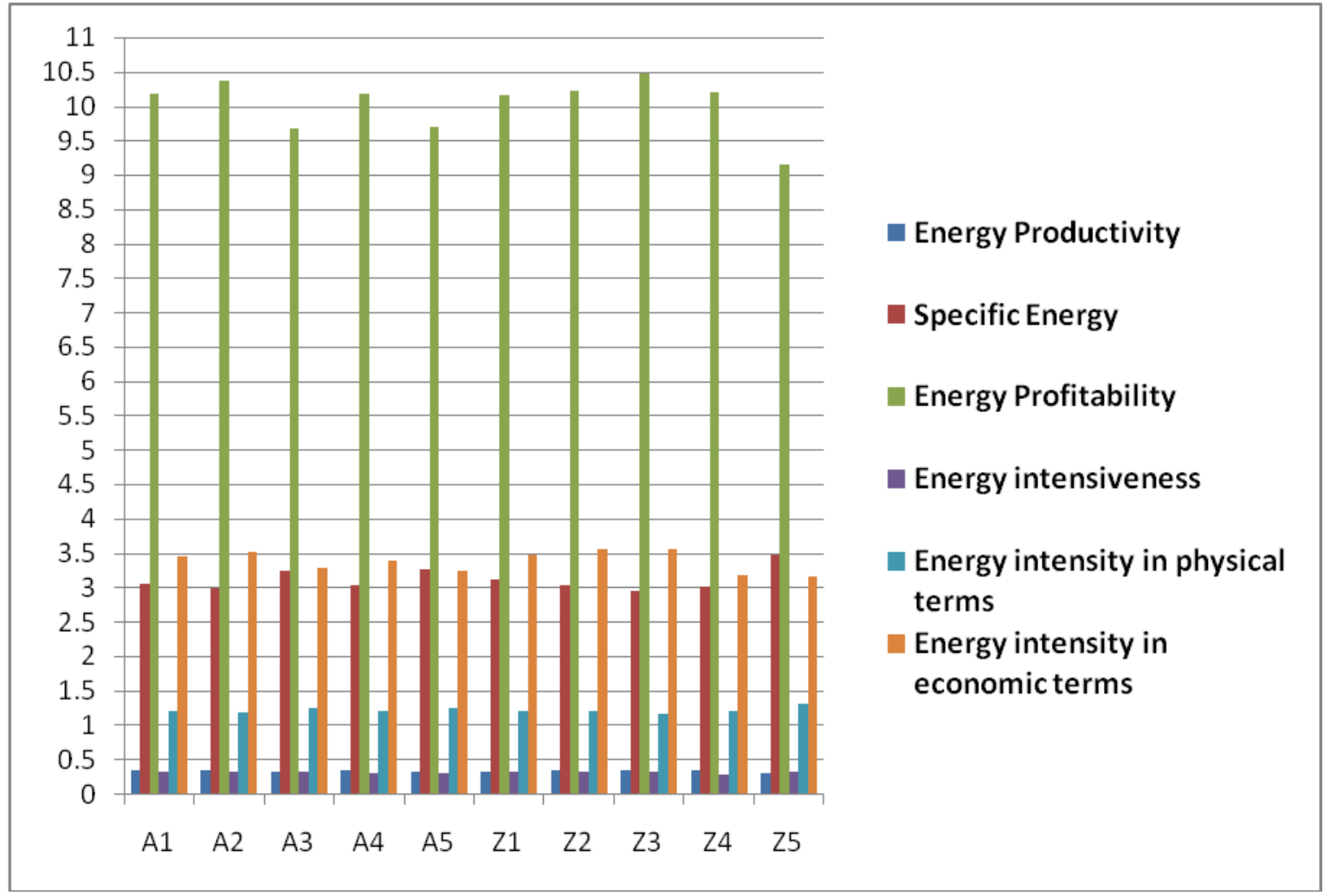

In case of alone application of herbicides, RM of carfentrazone and metsulfuron-methyl was more efficient in terms of energy calculations (input energy, total output energy, NE, EUE, energy productivity, energy intensity in economic terms etc.); this may be attributed to higher biological yield due better control of broad leaved weeds.

In conclusion among different planting techniques, drill sowing with $18 \mathrm{~cm}$ is most efficient method in respect of energy calculations (NE, EUE, energy profitability, specific energy, energy productivity, energy intensiveness, energy intensity in physical terms, energy intensity in economic terms) followed by three row bed planting and $20 \mathrm{~cm}$ row spacing. This may be attributed to total energy output (grain + straw). Tank mix application of pinoxaden $(50 \mathrm{~g} / \mathrm{ha})$ with RM of carfentrazone and metsulfuron-methyl is very efficient in terms of energy and recorded higher value of different energy calculations (EUE, energy profitability, specific energy, energy productivity, energy intensiveness, energy intensity in physical terms, energy intensity in economic terms). Weed free condition consumed higher input energy due to manual weeding compared to weed control by herbicide application.

\section{References}

Alam, M.S., Alam, M.R. and Islam, K.K. 2005. Energy Flow in Agriculture: Bangladesh. American Journal of Environmental Sciences, 1(3): 213220.

Beheshti Tabar, I., Keyhani, A., Rafiee, S.H. 2010. Energy balance in Iran's agronomy (1990-2006). Renewable and Sustainable Energy Review, 14: 849-855.

Chaharsooghi, A., Mousavi, H., Faraj, A. and Hosseini, S.J. 2008. Factors 
influencing the adoption of sustainable agricultural practices in irrigated wheat by wheat growers in the province 84-85. The Modern Agricultural Fall, 2(1): 79-92.

Chaudhary, V.P., Gangwar, B. and Pandey, D.K. 2006. Auditing of energy use and output of different cropping systems in India. Agricultural Engineering International: the CIGR Ejournal, 8: $1-13$.

Devasenapathy P., Senthilkumar G. and Shanmugam, P.M. 2009. Energy management in crop production. Indian Journal of Agronomy, 54(1): 50-90.

Dhaka, A.K., Pannu, R.K., Kumar, S., Malik, K. and Singh, B. 2015. Biological feasibility, economic viability and energy efficiency of intercropping fodder sorghum (Sorghum bicolor) in seed crop of dhaincha (Sesbania aculeata). Indian Journal of Agricultural Sciences, 85(1): 20-27.

Giampietro, M., Cerretelli, G. and Pimentel, D. 1992. Energy analysis of agricultural ecosystem management: human return and sustainability. Agricultural and Ecosystems Environment, 38: 219-244.

Hosseinpanahi, F. and Kafi, M. 2012. Assess the energy budget in farm production and productivity of potato (Solanum tuberosum L.) in Kurdistan, case study: Plain Dehgolan. Journal of Agroecology, 4: 159-169.

Khan, M.A. and Hossain, S.M.A. 2007. Study on energy input, output and energy use efficiency of major jute based cropping pattern. Bangladesh Journal of Scientific and Industrial Research, 42(2): 195-202.

Kumar, S., Dwivedi, S.K., Kumar, R., Mishra, J.S., Singh, S.K., Ved Prakash, Rao, K.K. and Bhatti, B.P. 2017. Productivity and energy use efficiency of wheat (Triticum aestivum) genotypes under different tillage options in rainfed ecosystem of middle Indo-Gangetic Plains. Indian Journal of Agronomy, 62 (1): 31-38.

Maurya, P., Kumar, V., Maurya, K.K, Kumawat, N., Kumar, R. and Yadav, M.P. 2014. Effect of potassium application on growth and yield of wheat varieties. The Bioscan, 11(4): 2411-2415.

Negi, S.C., Rana, S.S., Kumar, A., Subehia, S.K. and Sharma, S.K. 2016. Productivity and energy efficiency indices of diversified maize (Zea mays)-based cropping systems for mid hills of Himanchal Pradesh. Indian Journal of Agronomy, 61(1): 9-14.

Omani, A. and Chizari, M. 2008. Analysis of farming system sustainability of wheat farmers in Khuzestan province of Iran. Green Farming an International Journal of Agricultural Science, 6: 58.

Singh, H., Singh, A.K., Kushawa, H.L. and Singh, A. 2007. Energy consumption pattern of wheat production in India. Energy, 32: 1848-1854.

Sorokhaibam, S., Singh, N.A., and Nabachandra, L. 2016. Effect of liming, planting time and tillage on system productivity, profitability and resource-use efficiency of rice (Oryza sativa)-based cropping systems under rainfed valley land condition of North East India. Indian Journal of Agronomy, 61(2): 138-147.

Tuti, M.D., Mahanta, D., Bhattacharyya, R., Pandey, B.M., Bist, J.K. and Bhatt, J.C. 2013. Productivity, economics and energetic of Pigeonpea (Cajanus cajan) - based cropping system in mid hills of north west Himalaya. Indian Journal of Agronomy, 58(3): 303-8. 
How to cite this article:

Sudesh Devi, Virender Singh Hooda and Jagdev Singh. 2018. Energy Input-Output Analysis for Production of Wheat under Different Planting Techniques and Herbicide Treatments. Int.J.Curr.Microbiol.App.Sci. 7(07): 749-760. doi: https://doi.org/10.20546/ijcmas.2018.707.092 